\title{
MENGENAL METODE PENAFSIRAN AL QURAN
}

\author{
Hadi Yasin \\ hadiyasin.fai@uia.ac.ia
}

\begin{abstract}
Abstraksi
Tulisan sederhana ini bertujuan untuk mengungkap metodologi penafsitan ayat-ayat al-Quran, sekaligus untuk menolak metode-metode lain yang hendak digunakan untuk menfasirkan ayat-ayat al-Quran seperti hermenetika, suatu metode penafsiran untuk al-kitab : kitab suci agama kristen, yang oleh sebagian orang dicoba untuk digunakan menafsirkan Al-Quran. Analogi sederhananya adalah, ketika kita punya kendaraan, katakanlah mobil sedan Mercedes Benz C 300, lalu mau dikemudikan dengan menggunakan cara-cara mengemudikan sebuah bajaj (misalnya), tentu sangat tidak pas, akan jauh panggang dari api. Oleh karena itu, tulisan ini mencoba mengenalkan metode-metode tersebut pembaca.
\end{abstract}

\section{A. METODE PENAFSIRAN AL-QUR'AN}

\section{Pengertian Metode}

Metode adalah : Cara yang teratur dan terpikir baik-baik untuk mencapai maksud $^{1}$. Dalam Ensiklopedi Indonesia Metoda adalah : cara melakukan sesuatu ata cara mencapai pengetahuan ${ }^{2}$ Bentuk adalah : Sistem, susunan, pendekatan. ${ }^{3}$ Dalam hal ini berarti berbicara menganai hubungan tafsir al-Qur'an dengan media atau alat yang digunakan dalam menafsirkan al-Qur'an. Media untuk memperoleh pengetahuan dan pemahaman teks-teks atas nash al-Qur'an dapat berupa; nash (al-Qur'an dan alHadits), akal, ataupun intuisi. ${ }^{4}$ Sedangkan Corak adalah : Paham atau macam. ${ }^{5}$ Dalam

\footnotetext{
${ }^{1}$ Departemen Pendidikan dan Kebudayaan, Kamus Besar Bahasa Indonesia, Jakarta, Balai Pustaka. 1989. hlm. $580-581$.

${ }^{2}$ Hassan Shadily, Ensiklopedi Indonesia, Jakarta, PT. Ichtiar Baru - Van Hoeve. t.t. hlm. 2230.

${ }^{3}$ Departemen Pendidikan dan Kebudayaan, Kamus Besar Bahasa Indonesia, Jakarta, Balai Pustaka. 1989. Hlm. 103-104.

${ }^{4}$ Bard Al-Din Muhammad Abdullah al-Zarkasyi, Al-Burhan fi 'Ulum Al-Qur'an, Jilid II, dar al-Fikr, Beirut, 1988. hlm. 200

${ }^{5}$ Bard Al-Din Muhammad Abdullah al-Zarkasyi, Al-Burhan fi 'Ulum Al-Qur'an, Jilid II, dar al-Fikr, Beirut, 1988. hlm. 200Hlm. 173
} 
hal ini corak penafsiran adalah sekitar hubungan tafsir al-Qur'an dengan kecenderungan yang dimiliki mufasir yang bersangkutan.

\section{Bentuk-Bentuk Penafsiran Al-Quran}

Yang dimaksud dengan bentuk penafsiran disini ialah naw' (macam atau jenis) penafsiran. Sepanjang sejarah penafsiran Al-Qur'an, paling tidak ada dua bentuk penafsiran yang dipakai (diterapkan) oleh ulama' yaitu al-ma'tsur(riwayat) dan al$r a$ 'y (pemikiran).

\section{a). Bentuk Riwayat (Al-Ma'tsur)}

Penafsiran yang berbentuk riwayat atau apa yang sering disebut dengan "tafsir bi al-ma 'tsur" adalah bentuk penafsiran yang paling tua dalam sejarah kehadiran tafsir dalam khazanah intelektual Islam. Tafsir ini sampai sekarang masih terpakai dan dapat di jumpai dalam kitab-kitab tafsir seumpama tafsir al-Thabari, Tafsir ibn Katsir, dan lain-lain.

Dalam tradisi studi Al-Qur'an klasik, riwayat merupakan sumber penting di dalam pemahaman teks Al-Qur'an. Sebab, Nabi Muhammad SAW. diyakini sebagai penafsir pertama terhadap Al-Qur'an. Dalam konteks ini, muncul istilah "metode tafsir riwayat". Pengertian metode riwayat, dalam sejarah hermeneutik Al-Qur'an klasik, merupakan suatu proses penafsiran Al-Qur'an yang menggunakan data riwayat dari Nabi SAW. dan atau sahabat, sebagai variabel penting dalam proses penafsiran AlQur'an. Model metode tafsir ini adalah menjelaskan suatu ayat sebagaimana dijelaskan oleh Nabi dan atau para sahabat.

Para ulama sendiri tidak ada kesepahaman tentang batasan metode tafsir riwayat. Al-Zarqani, misalnya, membatasi dengan mendefinisikan sebagai tafsir yang diberikan oleh ayat Al-Qur'an. Sunnah Nabi, dan para sahabat. ${ }^{6}$ Ulama lain, seperti AlDzahabi, memasukkan tafsir tabi'in dalam kerangka tafsir riwayat, meskipun mereka tidak menerima tafsir secara langsung ari Nabi Muhammad SAW. Tapi, nyatanya kitabkitab tafsir yang selama ini diklaim sebagai tafsir yang menggunakan metode riwayat, memuat penafsiran mereka, seperti Tafsir Al-Thabari. ${ }^{7}$ Sedang Al-Shabuni memberikan pengertian lain tentang tafsir riwayat. Menurutnya tafsir riwayat adalah

\footnotetext{
${ }^{6}$ Muhammad ‘Abd Al-Azhim Al-Zarqani, Manahil Al-Irfan, hlm. 12.

${ }^{7}$ Al-Dzahabi, Al-Tafsir wa Al-Mufassirun, Kairo, Dar Al-Kutub Al-Haditsah, 1961, hlm. 152.
} 
model tafsir yang bersumber dari Al-Qur'an, Sunnah dan atau perkataan sahabat. ${ }^{8}$ Definisi ini nampaknya lebih terfokus pada material tafsir dan bukan pada metodenya. Ulamat Syi'ah berpandangan bahwa tafsir riwayat adalah tafsir yang dinukil dari Nabi dan para Imam Ahl-bayt. Hal-hal yang dikutib dari para sahabat dan tabi'in, menurut mereka tidak dianggap sebagai hujjah. ${ }^{9}$

Dari segi material, menafsirkan Al-Qur'an memang bisa dilakukan dengan menafsirkan antarayat, ayat dengan hadits Nabi, dan atau perkataan sahabat. Namun secara metodologis bila kita menafsirkan ayat Al-Qur'an dengan ayat lain dan atau dengan hadits, tetapi proses metodologisnya itu bukan bersumber dari penafsiran yang dilakukan Nabi, tentu semua itu sepenuhnya merupakan hasil intelektualisasi penafsir. Oleh karena itu, meskipun data materialnya dari ayat dan atau hadits Nabi dalam menafsirkan Al-Qur'an, tentu ini secara metodologis tidak bisa sepenuhnya disebut sebagai metode tafsir riwayat.

Jadi, terlepas dari keragaman definisi yang selama ini diberikan para ulama ilmu tafsir tentang tafsir riwayat di atas, metode riwayat di sini bisa didefinisikan sebagai metode penafsiran yang data materialnya "mengacu pada hasil penafsiran Nabi Muhammad SAW. yang ditarik dari riwayat pernyataan Nabi dan atau dalam bentuk asbab al-nuzulsebagai satu-satunya sember data otoritatif'. Sebagai salah satu metode, model metode riwayat dalam pengertian yang terakhir ini tentu statis, karena hanya tergantung pada data riwayat penafsiran Nabi. Dan juga harus diketahui bahwa tidak setiap ayat mempunyai asbab al-nuzul. ${ }^{10}$

\section{b). Bentuk Pemikiran (Al-Ra'y)}

Setelah berakhir masa salaf sekitar abad ke-3 H, dan peradaban Islam semakin maju dan berkembang, maka lahirlah berbagai mazhab dan aliran di kalangan umat. Masing-masing golongan berusaha menyakinkan pengikutnya dalam mengembangkan paham mereka. Untuk mencapai maksud itu, mereka mencari ayat-ayat Al-Qur'an dan Hadits-Hadits Nabi, lalu mereka tafsirkan sesuai dengan keyakinan yang mereka anut. Ketika inilah berkembangnya bentuk penafsiran al-ra'y (tafsir melalui pemikiran atau

\footnotetext{
${ }^{8}$ Muhammad Ali Al-Shabuni, A-Tibyan, hlm. 67.

${ }^{9}$ Ali Al-Awsi, Al-Thabathaba'i wa Manhajuh fi Tafsirih Al-Mizan, Taheran, Al-Jumhuriyyah AlIslamiyyah fi Iran, 1975, hlm. 103

${ }^{10}$ Islah Gusmian, Khazanah Tafsir Indonesia (dari Hermeneutika hingga Ideologi), Jakarta, Teraju Cet. I, 2003.. Hlm. 198
} 
ijtihad). Melihat berkembang pesatnya tafsir bi al-ra'y, maka tepat apa yang dikatakan Manna' al-Qaththan bahwa tafsir bi al-ra'y mengalahkan perkembangan tafsir bi alma'tsur.

Meskipun tafsir bi al-ra'y berkembang dengan pesat, namun dalam penerimaannya para ulama terbagi menadi dua : ada yang membolehkan ada pula yang melarangnya. Tapi setelah diteliti, ternyata kedua pendapat yang bertentangan itu hanya bersifat lafzhi (redaksional). Maksudnya kedua belah pihak sama-sama mencela penafsiran berdasarkan ra'y (pemikiran) semata tanpa mengindahkan kaedah-kaedah dan kriteria yang berlaku. Sebaliknya, keduannya sepakat membolehkan penafsiran AlQur'an dengan sunnah Rasul serta kaedah-kaedah yang mu;tabarah(diakui sah secara bersama). ${ }^{11}$

Dengan demikian jelas bahwa secara garis besar perkembangan tafsir sejak dulu sampai sekarang adalah melalui dua bentuk tersebut di atas, yaitu $b i$ alma'tsur (melalui riwayat) dan bi al-ra'y (melalui pemikiran atau ijtihad).

\section{Metode Penafsiran}

Yang dimaksud dengan metodologi penafsiran ialah ilmu yang membahas tentang cara yang teratur dan terpikir baik untuk mendapatkan pemahaman yang benar dari ayat-ayat A;-Qur'an sesuai kemampuan manusia.

Metode tafsir yang dimaksud di sini adalah suatu perangkat dan tata kerja yang digunakan dalam proses penafsiran Al-Qur'an. Perangkat kerja ini, secara teoritik menyangkut dua aspek penting yaitu : pertama, aspek teks dengan problem semiotik dan semantiknya. Kedua, aspek konteks di dalam teks yang mempresentasikan ruangruang sosial dan budaya yang beragam di mana teks itu muncul. ${ }^{12}$

Jika ditelusuri perkembangan tafsir Al-Qur'an sejak dulu sampai sekarang, maka akan ditemukan bahwa dalam garis besarnya penafsiran Al-Qur'an ini dilakukan dalam empat cara (metode), sebagaimana pandangan Al-Farmawi, yaitu : ijmaliy (global), tahliliy (analistis),

\footnotetext{
${ }^{11}$ Prof. Dr.Nasharuddin Baidan, Rekonstruksi Ilmu Tafsir, Yogyakarta, PT. Dana Bhakti Prima Yasa, 2000. hlm. $57-58$.

${ }^{12}$ Prof. Dr.Nasharuddin Baidan, Rekonstruksi Ilmu Tafsir, Yogyakarta, PT. Dana Bhakti Prima Yasa, 2000. hlm. 57 - 58 .
} 
muqaran (perbandingan), dan mawdhu'iy (tematik). ${ }^{13}$ Untuk lebih jelasnya di bawah ini diuraikan keempat metode tafsir tersebut secara rinci, yaitu : ${ }^{14}$

\section{a) Metode Ijmali (Global)}

\section{1). Pengertian}

Yang dimaksud dengan metode al-Tafsir al-Ijmali (global) ialah suatu metoda tafsir yang menafsirkan ayat-ayat Al-Qur'an dengan cara mengemukakan makna global. ${ }^{15}$ Pengertian tersebut menjelaskan ayat-ayat Al-Qur'an secara ringkas tapi mencakup dengan bahasa yang populer, mudah dimengerti dan enak dibaca. Sistematika penulisannya menurut susunan ayat-ayat di dalam mushhaf. Di samping itu penyajiannya tidak terlalu jauh dari gaya bahasa AL-Qur'an sehingga pendengar dan pembacanya seakan-akan masih tetap mendengar Al-Qur'an padahal yang didengarnya itu tafsirnya. ${ }^{16}$

Kitab tafsir yang tergolong dalam metode ijmali (global) antara lain : Kitab Tafsir Al-Qur'an al-Karimkarangan Muhammad Farid Wajdi,al-Tafsir alWasith terbitan Majma' al-Buhuts al-Islamiyyat, dan Tafsir al-Jalalain, serta Taj alTafasir karangan Muhammad 'Utsman al-Mirghani.

\section{2). Ciri-ciri Metode Ijmali}

Dalam metode ijmali seorang mufasir langsung menafsirkan Al-Qur'an dari awal sampai akhir tanpa perbandingan dan penetapan judul. Pola serupa ini tak jauh berbeda dengan metode alalitis, namun uraian di dalam Metode Analitis lebih rinci daripada di dalam metode global sehingga mufasir lebih banyak dapat mengemukakan pendapat dan ide-idenya. Sebaliknya di dalam metode global, tidak ada ruang bagi mufasir untuk mengemukakan pendapat serupa itu. Itulah sebabnya kitab-kitab Tafsir Ijmali seperti disebutkan di atas tidak memberikan penafsiran secara rinci, tapi

\footnotetext{
${ }^{13}$ Dr. Abdul Hay Al-Famawiy, Al-Bidayah fi Al-Tafsir Al-Maudhu'iy, Al-Hadharah Al-Arabiyah, Kairo, Cetakan II, 1977. hlm. 23

${ }^{14}$ Prof. Dr.Nasharuddin Baidan, Rekonstruksi Ilmu Tafsir, Yogyakarta, PT. Dana Bhakti Prima Yasa, 2000 hlm. $67-77$

${ }^{15}$ Abd al-Hayy al-Farmawi, al-Bidayah fi al-Tafsir al-Mawdhu'i, Dirasat Manhajiyyah Mawdhu'iyyah, (1977). hlm. 43 - 44.

${ }^{16}$ Abd al-Hayy al-Farmawi, al-Bidayah fi al-Tafsir al-Mawdhu'i, Dirasat Manhajiyyah Mawdhu'iyyah, (1977). hlm. 67.
} 
ringkas dan umum sehingga seakan-akan kita masih membaca Al-Qur'an padahal yang dibaca tersebut adalah tafsirnya; namun pada ayat-ayat tertentu diberikan juga penafsiran yang agak luas, tapi tidak sampai pada wilayah tafsir analitis.

\section{b) Metode Tahliliy (Analisis)}

\section{1). Pengertian}

Yang dimaksud dengan Metode Tahliliy (Analisis) ialah menafsirkan ayat-ayat Al-Qur'an dengan memaparkan segala aspek yang terkandung di dalam ayat-ayat yang ditafsirkan itu serta menerangkan makna-makna yang tercakup di dalamnya, sesuai dengan keahlian dan kecenderungan mufasir yang menafsirkan ayat-ayat tersebut.

Kalau kita lihat dari bentuk tinjauan dan kandungan informasi yang terdapat dalam tafsir tahliliy yang jumlah sangat banyak, dapat dikemukakan bahwa paling tidak ada tujuh bentuk tafsir, yaitu : ${ }^{17}$ Al-Tafsir bi al-Ma'tsur, Al-Tafsir bi al-Ra'yi, Al-Tafsir al-Fiqhi, Al-Tafsir al-Shufi, At-Tafsir al-Ilmi, dan Al-Tafsir al-Adabi al-Ijtima'i.

Sebagai contoh penafsiran metode tahliliy yang menggunakan bentuk Al-Tafsir bi al-Ma'tsur (Penafsiran ayat dengan ayat lain), misalnya : kata-kata almuttaqin (orang-orang bertakwa) dalam ayat 1 surat al-Baqarah dijabarkan ayat-ayat sesudahnya (ayat-ayat 3-5) yang menyatakan :

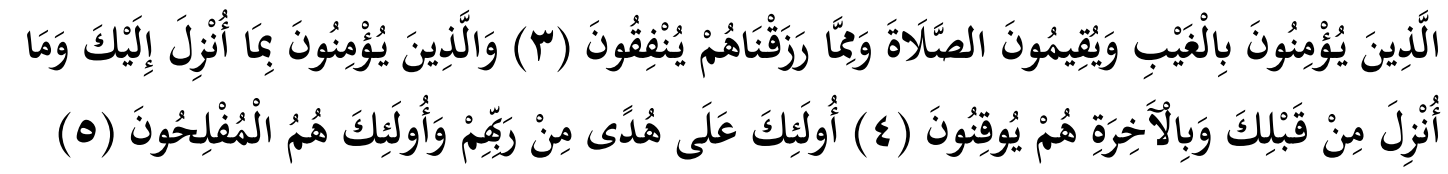

"Yaitu orang-orang yang beriman kepada yang ghaib, mendirikan salat, dan menafkahkan sebagian rizki yang Kami berikan kepada mereka, dan mereka yang beriman kepada Kitab (al-Qur'an) yang telah diturunkan kepadamu dan kitab-kitab yang telah diturunkan sebelummu, serta mereka yakin akan adanya (kehidupan) akherat. Mereka itulah yang tetap mendapat petunjuk dari Tuhannya, dan mereka orang-orang yang beruntung.” (QS. Al-Baqarah[2]:3-5)

\section{ґ) Ciri-ciri Metode Tahlili}

\footnotetext{
${ }^{17}$ Abd al-Hayy al-Farmawi, al-Bidayah fi al-Tafsir al-Mawdhu'i, Dirasat Manhajiyyah Mawdhu'iyyah, (1977). hlm. 49.
} 
Pola penafsiran yang diterapkan para penafsir yang menggunakan metode tahlili terlihat jelas bahwa mereka berusaha menjelaskan makna yang terkandung di dalam ayat-ayat Al-Qur'an secara komprehenshif dan menyeluruh, baik yang berbentuk al-ma 'tsur, maupun al-ra'y, sebagaimana. Dalam penafsiran tersebut, Al-Qur'an ditafsirkan ayat demi ayat dan surat demi surat secara berurutan, serta tak ketinggalan menerangkan asbab al-nuzuldari ayat-ayat yang ditafsirkan.

Penafsiran yang mengikuti metode ini dapat mengambil bentuk ma'tsur (riwayat) atau ra'y (pemikiran). Diantara kitab tahlili yang mengambil bentuk ma'tsur (riwayat) adalah :

a) Jami' al-Bayan 'an Ta'wil al-Qur'an al-Karim, karangan Ibn Jarir al-Thabari (w. $310 \mathrm{H}$ ) dan terkenal dengan Tafsir al-Thabari.

b) Ma'alim al-Tanzil, karangan al-Baghawi (w. $516 \mathrm{H}$ )

c) Tafsir al-Qur'an al-Azhim, karangan Ibn Katsir; dan

d) Al-Durr al-Mantsur fi al-Tafsir bi al-Ma'tsur, karangan al-Suyuthi (w. $911 \mathrm{H}$ )

e) Adapun tafsir tahlili yang mengambil bentuk $r a y^{\prime}$ banyak sekali, antara lain :

f) Tafsir al-Khazin, karangan al-Khazin (w. $741 \mathrm{H}$ )

g) Anwar al-Tanzil wa Asrar al-Ta'wil, karangan al-Baydhawi (w. $691 \mathrm{H}$ )

h) Al-Kasysyaf, karangan al-Zamakhsyari (w. $538 \mathrm{H}$ )

i) Arais al-Bayan fi Haqaiq al-Qur'an, karangan al-Syirazi (w. $606 \mathrm{H}$ )

j) Al-Tafsir al-Kabir wa Mafatih al-Ghaib, karangan al-Fakhr al-Razi (w. $606 \mathrm{H}$ )

k) Al-Jawahir fi Tafsir al-Qur'an, karangan Thanthawi Jauhari;

1) Tafsir al-Manar, karangan Muhammad Rasyid Ridha (w. 1935 M); dan lainlain

\section{c) Metode Muqarin (Komparatif)}

Pengertian metode muqarin (komparatif) dapat dirangkum sebagai berikut :

a. Membandingkan teks (nash) ayat-ayat Al-Qur'an yang memiliki persamaan atau kemiripan redaksi dalam dua kasus atau lebih, dan atau memiliki redaksi yang berbeda bagi satu kasus yang sama;

b. Membandingkan ayat Al-Qur'an dengan Hadits Nabi SAW, yang pada lahirnya terlihat bertentangan;

c. Membandingkan berbagai pendapat ulama' tafsir dalam menafsirkan Al-Qur'an. 
Jadi dilihat dari pengertian tersebut dapat dikelompokkan 3 objek kajian tafsir, yaitu 18 :

1) Membandingkan ayat Al-Qur'an dengan ayat Al-Qur'an yang lain;

Mufasir membandingkan ayat Al-Qur'an dengan ayat lain, yaitu ayat-ayat yang memiliki persamaan redaksi dalam dua atau lebih masalah atau kasus yang berbeda; atau ayat-ayat yang memiliki redaksi berbeda dalam masalah atau kasus yang (diduga) sama. Al-Zarkasyi mengemukakan delapan macam variasi redaksi ayat-ayat AlQur'an, ${ }^{19}$ sebagai berikut :

(a) Perbedaan tata letak kata dalam kalimat, seperti :

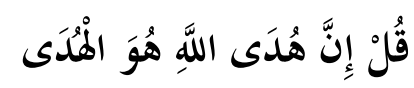

"Katakanlah : Sesungguhnya petunjuk Allah itulah (yang sebenarnya) petunjuk" (QS : al-Baqarah : 120)

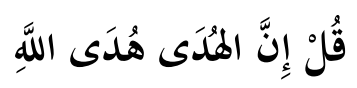

"Katakanlah : Sesungguhnya petunjuk (yang harus diikuti) ialah petunjuk Allah" (QS : al-An'am : 71)

(b) Perbedaan dan penambahan huruf, seperti :

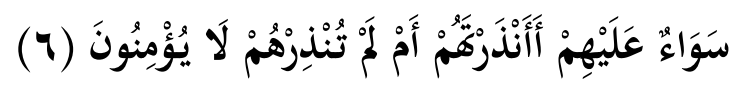

"Sama saja bagi mereka apakah kamu memberi peringatan kepada mereka ataukah kamu tidak memberi peringatan kepada mereka, mereka tidak akan beriman” (QS : alBaqarah : 6)

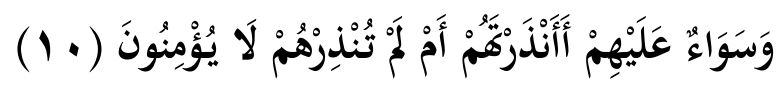

"Sama saja bagi mereka apakah kamu memberi peringatan kepada mereka ataukah tidak memberi peringatan kepada mereka, mereka tidak akan beriman" (QS : Yasin: 10)

\footnotetext{
${ }^{18}$ Prof. Dr. Quraish Shihab. dkk., Sejarah dan Ulum al-Qur'an, Jakarta, Pustaka Firdaus, 1999. hlm. 186-192.

${ }^{19}$ Al-Zarkasyi, al-Burhan fi Ulum al-Qur'an, Jilid. I, Beirut, Dar al-Fikr, 1988. hlm. 147 - 169.
} 
(c) Pengawalan dan pengakhiran, seperti :

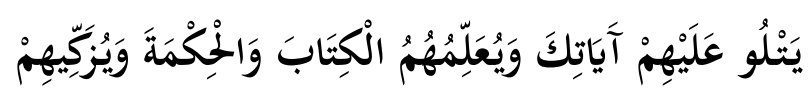

“...yang membaca kepada mereka ayat-ayat Engkau, dan mengajarkan kepada mereka al-Kitab (al-Qur'an) dan al-Hikmah serta mensucikan mereka" (QS. AlBaqarah :129)

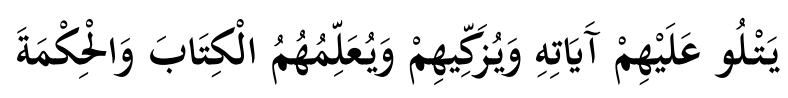

“...yang membaca ayat-ayatNya kepada mereka, mensucikan mereka, dan mengajarkan kepada mereka al-Kitab (al-Qur'an) dan al-Hikmah" (QS. Al-Jumu'ah [62]: 2)

(d) Perbedaan nakirah (indefinite noun) dan ma'rifah (definte noun), seperti :

$$
\text { فَاسْتَعْذْ بِاللَّهِ إِنَّهُ هُوَ السَّمِيعُ الْعَلِيمُ (ب) }
$$

“...mohonkanlah perlindungan kepada Allah. Sesungguhnya Dialah yang Maha Mendengar lagi Maha Mengetahui." (QS. Fushshilat : 36)

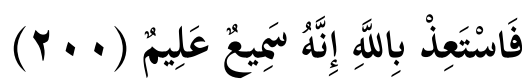

“...mohonkanlah perlindungan kepada Allah. Sesungguhnya Dia Maha Mendengar lagi Maha Mengetahui." (QS. Al-A'raf : 200)

(e) Perbedaan bentuk jamak dan tunggal, seperti :

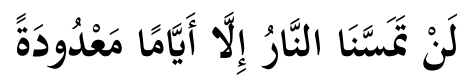

“...Kami sekali-kali tidak akan disentuh oleh api neraka, kecuali selama beberapa hari saja." (QS. Al-Baqarah : 80)

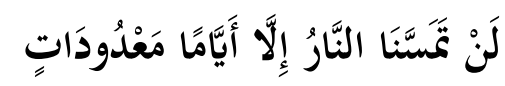

“...Kami sekali-kali tidak akan disentuh oleh api neraka, kecuali selama beberapa hari yang dapat dihitung." (QS. Ali-Imran : 24)

(f) Perbedaan penggunaan huruf kata depan, seperti : 


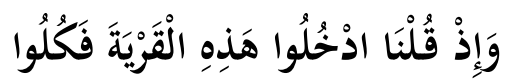

"Dan (ingatlah) ketika Kami berfirman : Masuklah kamu ke negeri ini, dan makanlah ..." (QS. Al-Baqarah : 58)

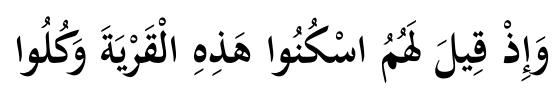

"Dan (ingatlah) ketika Kami berfirman : Masuklah kamu ke negeri ini, dan makanlah ..." (QS. Al-A'raf : 161)

(g) Perbedaan penggunaan kosa kata, seperti :

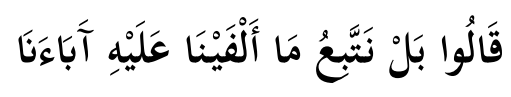

"Mereka berkata : Tidak, tetapi kami hanya mengikuti apa yang telah kami dapati (alfayna) dari (perbuatan) nenek moyang kami." (QS. Al-Baqarah : 170)

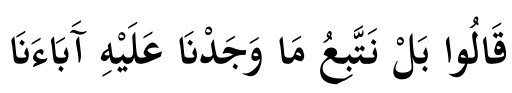

"Mereka berkata : Tidak, tetapi kami hanya mengikuti apa yang telah kami dapati (wajadna) dari (perbuatan) nenek moyang kami." (QS. Luqman : 21)

(h) Perbedaan penggunaan idgham (memasukkan satu huruf ke huruf lain), seperti :

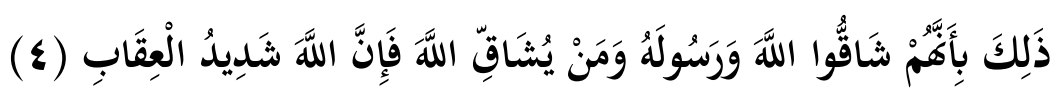

"Yang demikian ini adalah karena sesungguhnya mereka menentang Allah dan Rasulnya, barang siapa menentang (yusyaqq) Allah, maka sesungguhnya Allah sangat keras hukuman-Nya." (QS. Al-Hasyr : 4)

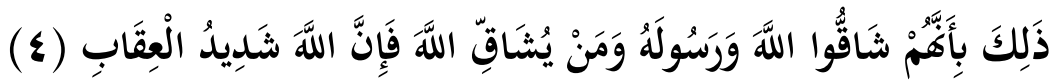

"Yang demikian ini adalah karena sesungguhnya mereka menentang Allah dan Rasulnya. Barang siapa menentang (yusyaqiq) Allah dan Rasul-Nya, maka sesungguhnya Allah sangat keras hukuman-Nya." (QS. Al-Hasyr : 4)

Dalam mengadakan perbandingan antara ayat-ayat yang berbeda redaksi tersebut di atas, ditempuh beberapa langkah : (1) menginventa-risasi ayat-ayat alQur'an yang memiliki redaksi yang berbeda dalam kasus yang sama atau yang sama 
dalam kasus berbeda, (2) Mengelompokkan ayat-ayat itu berdasarkan persamaan dan perbedaan redaksinya, (3) Meneliti setiap kelompok ayat tersebut dan menghubungkannya dengan kasus-kasus yang dibicarakan ayat bersangkutan, dan (4) Melakukan perbandingan.

1). Membandingkan ayat dengan Hadits;

Mufasir membandingkan ayat-ayat al-Qur'an dengan hadits Nabi saw yang terkesan bertentangan. Dan mufasir berusaha untuk menemukan kompromi antara keduanya. Contoh perbedaan antara ayat al-Qur'an surat al-Nahl/16 : 32 dengan hadits riwayat Tirmidzi dibawah ini :

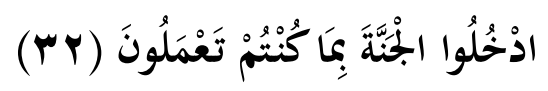

"Masuklah kamu ke dalam surga disebabkan apa yang telah kamu kerjakan" (QS. AlNahl : 32)

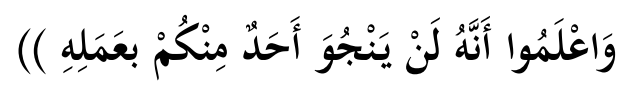

"Ketahuilah, bahwa Tidak akan bertuntung salah seorang pun diantara kamu (masuk ke dalam surga) disebabkan perbuatannya” (HR. Tirmidzi)

Antara ayat al-Qur'an dan hadits tersebut di atas terkesan ada pertentangan. Untuk menghilangkan pertentangan itu, al-Zarkasyi mengajukan dua cara :

Pertama, dengan menganut pengertian harfiah hadits, yaitu bahwa orang-orang tidak masuk surga karena amal perbuatannya, tetapi karena ampunan dan rahmat Tuhan. Akan tetapi, ayat di atas tidak disalahkan, karena menurutnya, amal perbuatan manusia menentukan peringkat surga yang akan dimasukinya. Dengan kata lain, posisi seseorang di dalam surga ditentukan amal perbuatannya. Pengertian ini sejalan dengan hadits lain, yaitu :

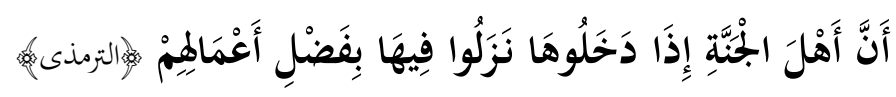

"Sesungguhnya ahli surga itu, apabila memasukinya, mereka mendapat posisi di dalamnya berdasarkan keutamaan perbuatannya”. (HR. Tirmidzi) 
Kedua, dengan menyatakan bahwa huruf $b a^{\prime}$ pada ayat di atas berbeda konotasinya dengan yang ada pada hadits tersebut. Pada ayat berarti imbalan, sedangkan pada hadits berarti sebab.

2). Membandingkan pendapat para mufasir.

Mufasir membandingkan penafsiran ulama tafsir, baik ulama salaf maupun ulama khalaf, dalam menafsirkan ayat-ayat al-Qur'an, baik yang bersifat manqul (altafsir al-ma'tsur) maupun yang bersifat ra'yu(al-tafsir bi al-ra'yi).

Manfaat yang dapat diambil dari metode tafsir ini adalah : 1) membuktikan ketelitian al-Qur'an; 2) membuktikan bahwa tidak ada ayat-ayat al-Qur'an yang kontradiktif; 3) memperjelas makna ayat; dan 4) tidak menggugurkan suatu hadits yang berkualitas sahih.

Sedang dalam hal perbedaan penafsiran mufasir yang satu dengan yang yang lain, mufasir berusaha mencari, menggali, menemukan, dan mencari titik temu di antara perbedaan-perbedaan itu apabila mungkin, dan mentarjih salah satu pendapat setelah membahas kualitas argumentasi masing-masing.

\section{3). Ciri-ciri Metode Muqarin}

Perbandingan adalah ciri utama bagi Metode Komparatif. Disini letak salah satu perbedaan yang prinsipil antara metode ini dengan metode-metode lain. Hal ini disebabkan karena yang dijadikan bahan dalam memperbandingkan ayat dengan ayat atau ayat dengan hadits, adalah pendapat para ulama tersebut dan bahkan dalam aspek yang ketiga. Oleh sebab itu jika suatu penafsiran dilakukan tanpa membandingkan berbagai pendapat yang dikemukakan oleh para ahli tafsir, maka pola semacam itu tidak dapat disebut "metode muqarrin".

\section{(d) Metode Mawdhu'iy (Tematik)}

\section{1). Pengertian}

Yang dimaksud dengan metode mawdhu'iy ialah membahas ayat-ayat AlQuran sesuai dengan tema atau judul yang telah ditetapkan. Semua ayat yang berkaitan, dihimpun. Kemudian dikahi secara mendalam dan tuntas dari berbagai aspek yang terkait dengannya seperti asbab al-nuzul, kosa kata dan sebagainya. Semuanya dijelaskan secara rinci dan tuntas, serta didukung oleh dalil-dalil atau fakta yang dapat 
dipertanggungjawabkan secara ilmiah; baik argumen itu berasal dari Al-Qur'an dan Hadits, maupun pemikiran rasional.

\section{2). Ciri-ciri Metode Mawdhu'iy}

Yang menjadi ciri utama metode ini ialah menonjolkan tema, judul atau topik pembahasan; sehingga tidak salah bila di katakan bahwa metode ini juga disebut metode "topikal". Jadi mufasir mencari tema-tema atau topik-topik yang ada si tengah masyarakat atau berasal dari Al-Qur'an itu sendiri, ataupun dari yang lain. Kemudian tema-tema yang sudah dipilih itu dikaji secara tuntas dan menyeluruh dari berbagai aspek, sesuai dengan kapasitas atau petunjuk yang termuat di dalam ayat-ayat yang ditafsirkan tersebut. Artinya penafsiran yang diberikan tak boleh jauh dari pemahaman ayat-ayat Al-Qur'an, agar tidak terkesan penafsiran tersebut berangkat dari pemikiran atau terkaan belaka (al-Ra'y al-Mahdh).

Sementara itu Prof. Dr. Abdul Hay Al-Farmawy seorang guru besar pada Fakultas Ushuluddin Al-Azhar, dalam bukunya Al-Bidayah fi Al-Tafsir AlMawdhu'i mengemukakan secara rinci langkah-langkah yang hendak ditempuh untuk menerapkan metode mawdhu'i. Langkah-langkah tersebut adalah :

(a) Menetapkan masalah yang akan dibahas (topik);

(b) Menghimpun ayat-ayat yang berkaitan dengan masalah tersebut;

(c) Menyusun runtutan ayat sesuai dengan masa turunnya, disertai pengetahuan tentang asbab al-nuzulnya;

(d) Memahami korelasi ayat-ayat tersebut dalam surahnya masing-masing;

(e) Menyusun pembahasan dalam kerangka yang sempurna (out-line);

(f) Melengkapi pembahasan dengan hadits-hadits yang relevan dengan pokok bahasan;

(g) Mempelajari ayat-ayat tersebut secara keseluruhan dengan jalan menghimpun ayat-ayatnya yang mempunyai pengertian yang sama, atau mengkompromikan antara yang 'am (umum) dan yang khas (khusus), mutlak danmuqayyad (terikat), 
atau yang pada lahirnya bertentangan, sehingga kesemuanya bertemu dalam satu muara, tanpa perdebatan atau pemaksaan. ${ }^{20}$

\section{ANALISIS}

Yang paling populer dari keempat metode penafsiran yang disebutkan di atas, menurut Dr. Quraish Shihab ${ }^{21}$ adalah metode tahliliy, dan metode mawdhu'iy. Namun begitu dari beberapa tokoh analis Islam, kedua metode tersebut disamping mempunyai kelebihan disatu sisi, pada sisi yang lain mempunyai kelemahan-kelemahan.

Metode tahliliy atau yang dinamai oleh Baqir Al-Shadr sebagai metode tajzi 'iy. ${ }^{22}$ Walaupun sangat luas - karena menafsirkan ayat-ayat Al-Qur'an dari berbagai segi - namun tidak menyelesaikan satu pokok bahasan, karena seringkali satu pokok bahasan diuraikan sisinya atau kelanjutannya, pada ayat lain. Pemikir Al-Jazair kontemporer, Malik bin Nabi, menilai bahwa upaya para ulama menafsirkan Al-Qur'an dengan metode tahliliy itu, tidak lain kecuali dalam rangka upaya mereka meletakkan dasar-dasar rasional bagi pemahaman akan kemukjizatan Al-Qur'an. ${ }^{23}$ Terlepas dari bernar tidaknya pendapat Malik tersebut, namun yang jelas kemukjizatan Al-Qur'an tidak ditujukan kecuali kepada mereka yang tidak percaya. Hal ini dapat dibuktikan dengan memperhatikan rumusan definisi mukjizat di mana terkadang di dalamnya unsur tahaddiy (tantangan), sedangkan seorang Muslim tidak perlu ditantang karena dengan keislamannya ia telah menerima. Bukti kedua dapat dilihat dari teks ayat-ayat yang berbicara tentang keluarbiasaan Al-Qur'an yang selalu dimulai dengan kalimat إن

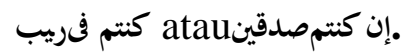

Kalau tujuan penggunaan metode tahliliy seperti yang diungkapkan Malik di atas, maka terlepas dari keberhasilan atau kegagalan mereka, yang jelas untuk masyarakat Muslim dewasa ini, paling tidak persoalan tersebut bukan lagi merupakan persoalan yang mendesak. Karenanya, untuk masa kini, pengembangan metode

\footnotetext{
${ }^{20}$ Abd al-Hayy al-Farmawi, al-Bidayah fi al-Tafsir al-Mawdhu'i, Dirasat Manhajiyyah Mawdhu'iyyah, (1977).. hlm. $114-115$.

${ }^{21}$ Prof. Dr. Quraish Shihab. dkk., Sejarah dan Ulum al-Qur'an, Jakarta, Pustaka Firdaus, 1999., hlm. 83-91 dan 11-126

${ }^{22}$ Muhammad Baqir Al-Shadr, Al-Tafsir Al-Maudhu'iy wa Al-Tafsir Al-Tajzi'iy fi Al-Qur'an AlKarim, Dar Al-Ta'ruf lil Matbu'at, Beirut, 1980, hlm. 10.

${ }^{23}$ Malik bin Nabi, Le Phenomena Quranique, diterjemahkan kedalam bahasa Arab oleh Prof. Dr. Abdussabur Syahin dengan judul Az-Zahirah Al-Qur'aniyah, Dar Al-Fikr, Lebanon, t.t. hlm. 58
} 
penafsiran menjadi amat dibutuhkan, apalagi jika kita sependapat dengan Baqir AlShadr - Ulama' Syi'ah Irak itu - yang menilai bahwa metode tahliliy telah menghasilkan pandangan-pandangan parsial serta kontradiktif dalam kehidupan umat Islam. ${ }^{24}$ Dapat ditambahkan bahwa para penafsir yang menggunakan metode tahliliy tidak jarang hanya berusaha menemukan dalil atau lebih tepat dalih pembenaran pendapatnya dengan ayat-ayat Al-Qur'an. Selain itu, terasa sekali bahwa metode ini tidak mampu memberi jawaban tuntas terhadap persoalan-persoalan yang dihadapi sekaligus tidak banyak memberi pagar-pagar metodologis yang dapat mengurangi subjektivitas mufasirnya.

Kelemahan lain yang dirasakan dalam tafsir-tafsir yang menggunakan metode tahliliy dan yang masih perlu dicari penyebabnya - apakah pada diri kita atau metode mereka - adalah bahwa bahasa-bahasanya dirasakan sebagai "mengikat" generasi berikutnya. Hal ini mengacu kepada penafsiran persoalan-persoalan khusus yang mereka alami dalam masyarakat mereka, sehingga uraian yang bersifat teoritis dan umum itu mengesankan bahwa itulah pandangan Al-Qur'an untuk waktu dan tempat. ${ }^{25}$

Sedang metode mawdhu'iy yang mana mufasirnya berupaya menghimpun ayatayat Al-Qur'an dari berbagai surah dan yang berkaitan dengan persoalan atau topik yang ditetapkan sebelumnya. Kemudian, penafsir membahas dan menganalisis kandungan ayat-ayat tersebut sehingga menjadi satu kesatuan yang utuh.

Beberapa keistemewaan metode mawdhu'iy antara lain : (1) Menghindari problem atau kelemahan metode lain; (2) Menafsirkan ayat dengan ayat atau dengan hadits Nabi, satu cara terbaik dalam menafsirkan Al-Qur'an; (3) Kesimpulan yang dihasilkan mudah dipahami; dan (4) Metode ini memungkinkan seseorang untuk menolak anggapan adanya ayat-ayat yang bertentangan dalam Al-Qur'an. Ia sekaligus dapat dijadikan bukti bahwa ayat-ayat Al-Qur'an sejalan dengan perkembangan ilmu pengetahuan dan masyarakat.

Disamping itu ketika metode mawdhu'iy disandingkan dengan metode-metode lain, maka akan muncul perbedaan-perbedaan. Perbedaan tersebut antara lain :

\footnotetext{
${ }^{24}$ Muhammad Baqir Al-Shadr, Al-Tafsir Al-Maudhu'iy wa Al-Tafsir Al-Tajzi'iy fi Al-Qur'an AlKarim, Dar Al-Ta'ruf lil Matbu'at, Beirut, 1980, hlm hlm. 12.

${ }^{25}$ Prof. Dr. Quraish Shihab. dkk., Sejarah dan Ulum al-Qur'an, Jakarta, Pustaka Firdaus, 1999., hlm. 87
} 
Perbedaan Metode Mawdhu'iy dengan Metode Analisis

\begin{tabular}{|c|c|}
\hline Metode I & Metode \\
\hline 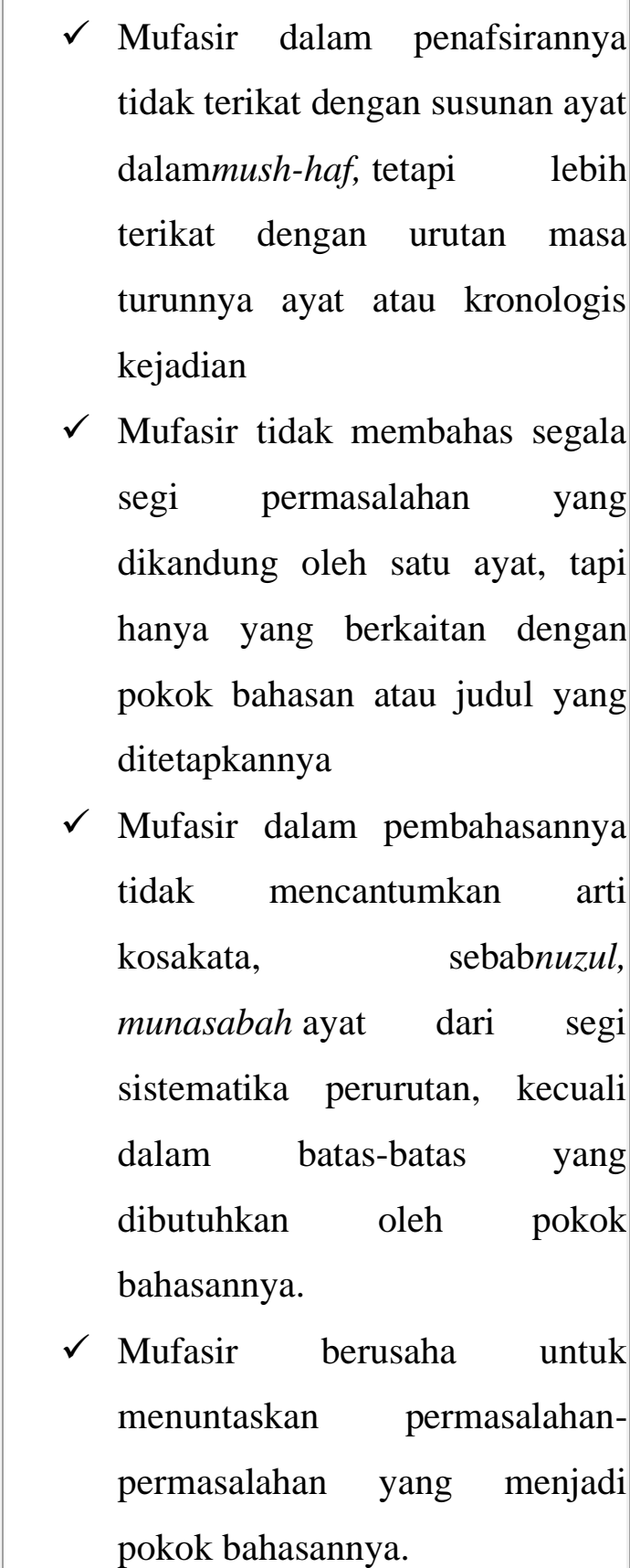 & 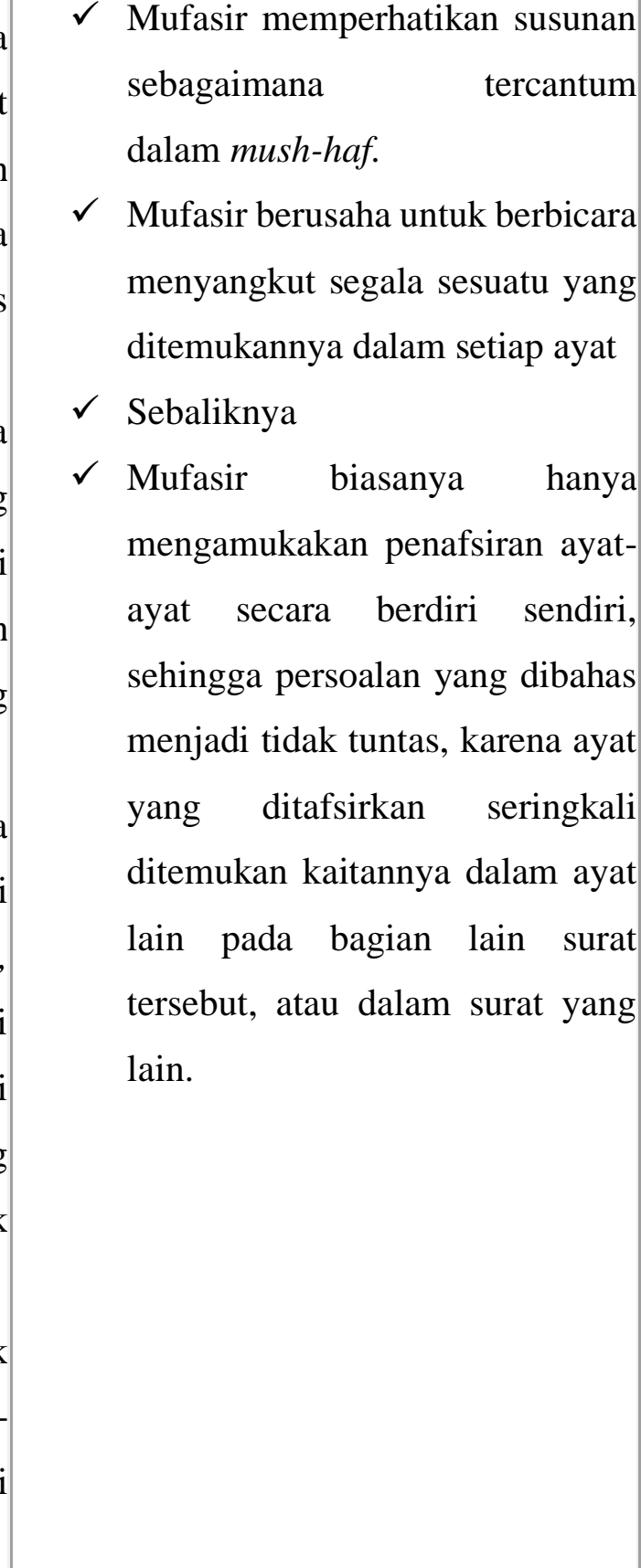 \\
\hline
\end{tabular}

Perbedaan Metode Mawdhu'iy dengan Metode Komparasi

Contoh perbedan antara metode mawdhu'iy dengan metode komparasi, adalah yang khusus membandingkan antara ayat dengan ayat seperti ayat : 
Surat Al-An'am ayat 151 :

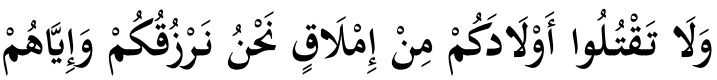

Surat Al-Isra' ayat 31 :

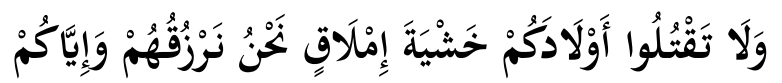

Atau perbedaan antara :

Surat Al-A'raf ayat 12

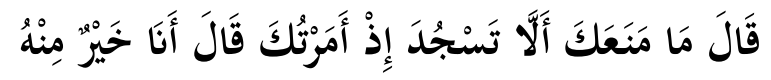

Surat Shad ayat 75

مَا مَنَعَكَ أَنْ تَسْجُحُدَ لِمَا خَلَقْتُ بِيَدَيَّ

\begin{tabular}{|c|c|}
\hline Metode Mawdhu'iy & Metode Komparasi \\
\hline $\begin{array}{l}\checkmark \text { Mufasir disamping menghimpun } \\
\text { semua ayat yang berkaitan } \\
\text { dengan masalah yang dibahas, ia } \\
\text { juga mencari persamaan- } \\
\text { persamaan, serta segala petunjuk } \\
\text { yang dikandungnya selama } \\
\text { berkaitan dengan pokok bahasan } \\
\text { yang ditetapkan. }\end{array}$ & $\begin{array}{l}\checkmark \text { Mufasir biasanya hanya } \\
\text { menjelaskan hal-hal yang } \\
\text { berkaitan dengan perbedaan } \\
\text { kandungan yang dimaksud oleh } \\
\text { masing-masing ayat tersebut atau } \\
\text { perbedaan kasus atau masalah } \\
\text { Seperti misal : Al-Khatib Al- } \\
\text { Iskafi dalam kitabnya Durrah } \\
\text { Al-Tanzil wa Ghurrah Al- } \\
\text { Ta'wil, (tidak mengarahkan } \\
\text { pandangannya kepada petunjuk- } \\
\text { petunjuk yang dikandung oleh } \\
\text { ayat-ayat yang dibandingkan) }\end{array}$ \\
\hline
\end{tabular}




\section{BAB}

\section{PENUTUP}

\section{A. KESIMPULAN}

(1) Tafsir terdiri dari empat bagian : pertama, yang dapat dimengerti secara umum oleh orang-orang Arab berdasarkan pengetahuan bahasa mereka; kedua, yang tidak ada alasan bagi seseorang untuk tidak mengetahuinya; ketiga, yang tidak diketahui kecuali oleh ulama; dan keempat, yang tidak diketahui kecuali oleh Allah.

(2) Ada dua jenis pembatasan dalam tafsir al-Qur'an, yaitu : menyangkut materi ayatayat dan menyangkut syarat-syarat penafsiran.

(3) Dalam penafsiran al-Qur'an ada dua bentuk yang selama ini dipakai (diterapkan) oleh para ulama, yaitu : al-Tafsir bi al-Ma'tsur (Riwayat), dan al-Tafsir bi al$R a^{\prime} y$ (Pemikiran)

(4) Secara garis besarnya ada empat cara (metode) penafsiran al-Qur'an yang dipakai sejak dahulu sampai sekarang, yaitu :ijmaliy (global), tahliliy (analistis), muqaran (perbandingan), dan mawdhu'iy (tematik)

(5) Yang paling populer dari keempat metode penafsiran, menurut Dr. Quraish Shihab adalah : metode tahliliy (analistis), dan metode mawdhu'iy (tematik) namun disamping populer menurut para ulama tafsir, metode ini memiliki kelemahankelemahan disamping memiliki kelebihan.

\section{B. SARAN}

1. Belajar memang harus pada orang yang benar dan dengan cara yang benar

2. Jika ada suatu ajaran yang tidak sejalan dengan al-Quran dan sunnah, maka kita tinggalkan ajaran itu, lalu kita pilih al-Quran dan sunnah. 


\section{BIBLIOGRAFI}

1 Abd al-Hayy al-Farmawi, al-Bidayah fi al-Tafsir al-Mawdhu'i, Dirasat Manhajiyyah Mawdhu'iyyah, (1977).

2 Ali Al-Awsi, Al-Thabathaba'i wa Manhajuh fi Tafsirih AlMizan, Taheran, Al-Jumhuriyyah Al-Islamiyyah fi Iran, 1975.

3 Al-Imam Ibnu Taymiyah, Minhaj As Sunnah.

4 Bard Al-Din Muhammad Abdullah al-Zarkasyi, Al-Burhan fi 'Ulum AlQur'an, Jilid II, dar al-Fikr, Beirut, 1988. hlm. 200Hlm. 173

5 Departemen Pendidikan dan Kebudayaan, Kamus Besar Bahasa Indonesia, Jakarta, Balai Pustaka. 1989.

6 Dr Muhammad Sayyid Husein Adz-Dzahaby At Tafsir Wa Al Mufassirun

7 Dr. Muhammad as-Sayyid Jibril, Madkhal Ila Manahijil Mufassirin, Jami`'ah Al-Azhar

8 Fahmi Salim, MA, Kritik Terhadap Studi Al-Quran Kalum Liberal, Perspektif.

9 Hassan Shadily, Ensiklopedi Indonesia, Jakarta, PT. Ichtiar Baru - Van Hoeve.

10 Ibnu Hajar al-Asqallani al-Ishabah fi Tamyiz Al Shahabah, vol. 1/10 al Maktabah al-Ashriyah.

11 Ibnu Hajar al-Asqallani al-Ishabah fi Tamyiz Al Shahabah, vol. 1/10 al Maktabah al-Ashriyah.

12 Islah Gusmian, Khazanah Tafsir Indonesia (dari Hermeneutika hingga Ideologi), Jakarta, Teraju Cet. I, 2003.

13 Kamus Besar Bahasa Indonesia (Elektronik)

14 Malik bin Nabi, Le Phenomena Quranique, diterjemahkan kedalam bahasa Arab oleh Prof. Dr. Abdussabur Syahin dengan judul Az-Zahirah AlQur'aniyah, Dar Al-Fikr, Lebanon,

15 Manna' Khalil al-Qattan, Mabahits Fii Ulumil Qur an, diterjemahkan oleh Drs Mudzakir AS, Studi Ilmu-Ilmu Al-Quran, Litera Antar Nusa.

16 Muhammad 'Abd Al-Azhim Al-Zarqani, Manahil Al-Irfan.

17 Muhammad Ali Al-Shabuni, A-Tibyan,

18 Muhammad Ali As-Shabuny, At-Tibyan fii Umumil Quran, Maktabah AlGhazaly, Dimasyq, Muassasah Manahilil Irfan, Beirut.

19 Muhammad Baqir Al-Shadr, Al-Tafsir Al-Maudhu'iy wa Al-Tafsir AlTajzi 'iy fi Al-Qur'an Al-Karim, Dar Al-Ta'ruf lil Matbu'at, Beirut, 1980, hlm. 10 .

20 Muhammad Baqir Al-Shadr, Al-Tafsir Al-Maudhu'iy wa Al-Tafsir AlTajzi'iy fi Al-Qur'an Al-Karim, Dar Al-Ta'ruf lil Matbu'at, Beirut, 1980, hlm hlm. 12. 
21 Prof Dr H Muhammad Hisyam, ceramah, materi kuliah S3 di PTIQ tanggal 5 Nov 2016

22 Prof. Dr. M. Quraish Shihab, MA. Membumikan Al-Quran, Mizan

23 Prof. Dr. M. Quraish Shihab, MA. Mukjizat Al-Quran, Mizan

24 Prof. Dr. M. Quraish Shihab, MA. Wawasan Al-Quran, Mizan

25 Prof. Dr. Quraish Shihab. dkk., Sejarah dan Ulum al-Qur'an, Jakarta, Pustaka Firdaus, 1999.

26 Prof. Dr.Nasharuddin Baidan, Rekonstruksi Ilmu Tafsir, Yogyakarta, PT. Dana Bhakti Prima Yasa, 2000.

27 Sulaiman Bin Shalih al-Kharasyi, Menimbang Ajaran syi ah, 188 Pertanyaan Kritis, Pustaka At-Tazkia

28 Syaikh Abdullah Bin Muhammad, Menyingkap Hakikat Aqidah Syi`ah, Jaringan Pembelaan Terhadap Sunnah. www.d-sunnah.net

29 Tim Penulis MUI Pusat, Panduan Majelis Ulama Indonesia Mengenal \& Mewaspadai Penyimpangan Syi'ah di Indonesia. Majelis Ulama Indonesia. 